\title{
Bioconversion Rice Bran and Cassava Peel into Yeasts Cell Walls Mannoprotein as Environmental Friendly Antioxidant
}

\author{
Novia Oktaviani ${ }^{1}$, Ki Ageng Sarwono ${ }^{2}$ and Gemilang lara Utama ${ }^{1,3^{*}}$ \\ ${ }^{1}$ Faculty of Agro-Industrial Technology, Universitas Padjadjaran, Jantinangor, West Java, Indonesia \\ ${ }^{2}$ Gradute School and Faculty of Bioresource, Mie University, Tsu, Mie, Japan \\ ${ }^{3}$ Center for Environment and Sustainability Science, Universitas Padjadjaran, Bandung, West Java, Indonesia
}

\begin{abstract}
Rice bran and cassava peel can be used as nutrients for yeast growth to produce mannoproteins. Currently, the application of yeast cell wall mannoproteins has only limited use in the food sector such as winemaking, stabilizers and emulsifiers in salad dressings. The functional and biological abilities of mannoproteins are influenced by their constituent components. Currently, has been found research that mannan and protein, which are components of mannoproteins, have potential as antioxidants. Based on a literature review, mannoproteins have potential as antioxidants because many hydroxyl groups are found in the chain of bonds. All mannan fractions have superior scavenging activity against hydroxyl groups at a concentration of $3.2 \mathrm{mg} / \mathrm{mL}$ while to produce scavenging activity against oxidative superoxide groups requires $3.3 \mathrm{mg} / \mathrm{mL}$. Utilization of rice bran and cassava peels through the production of mannoproteins as antioxidants is an environmental friendly action because it can reduce the volume and utilize agro-industrial waste, so that environmental pollution can be better controlled.
\end{abstract}

\section{Introduction}

Yeast plays an important role in the food industry. One of the yeast components that have produced many benefits is mannoproteins. Mannoprotein is a constituent of yeast cell walls with the second largest composition after $\beta$-glucan [32]. Mannoproteins have bonds between mannan (polymer of mannose) and proteins which eventually form mannoproteins. Mannoprotein represents $30-40 \%$ dry weight of the total cell wall [25].

Even though it has been widely used, the role of mannoproteins from yeast cell walls in the new food industry is focused on its function as an emulsifier and stabilizer in salad dressings or mayonnaise [7]. The functional and biological abilities of mannoproteins are influenced by their constituent components. Currently, research has been found that states that mannan and protein, which are components of mannoproteins, have potential as antioxidants [39].

To obtain yeast mannoproteins which have potential as antioxidants, one of the things that must be considered is the availability of nutrients in the media used by yeast to grow. The most important nutrients needed are carbohydrates. The substrate that contains high carbohydrates but has not been widely used is a byproduct of food products. Some examples of byproducts of food products that have potential as a yeast growth medium are rice bran and cassava peel (BKUK). This is supported by the research of Ugah and Nwoba (2018) that the results of rice and cassava peels can be used as a growth medium for Saccharomyces carlbergensis.

Rice bran is used as a yeast growth medium because it contains high carbohydrates of around $84.36 \%$ [26]. Wachid dan Ningrum, (2017) state that cassava peels contain carbohydrates of $44-59 \%$ so that with this carbohydrate content, BKUK has the potential to grow yeast. The nutrients contained in the by-products of these food products are used as a source of carbon and energy for yeast growth. The utilization of food byproducts consisting of BKUK will be related to the yeast growth population. This population shows the number of cell walls, where the cell wall will represent mannoprotein biomass. This is because the cell walls of yeast are composed of mannoproteins [32].

\section{Yeasts Cell Walls Mannoprotein}

The main components of yeast cell walls are polysaccharides and glycoproteins (Herrera et al., 2006) - The glycoproteins in the yeast cell walls are mannoproteins. Mannoprotein is the second most important component after $\beta$-glucan [32]. Mannoprotein represents $30 \%$ dry weight of the total cell wall [25]. Mannoprotein is a compound consisting of 10 to $20 \%$ protein and 80 to $90 \%$ mannose.

According to $\mathrm{Li}$ and Karboune (2018) mannoproteins can be divided into three groups: (i) not covalently bound, (ii) covalently bound to structural glucans and (iii) disulfides bound to other proteins

\footnotetext{
* Corresponding author: noviaoktaviani589@gmail.com
} 
covalently bound to cell wall glucans. The molecular weight of yeast mannoproteins ranges from $25 \mathrm{kDa}$ to more than $250 \mathrm{kDa}$ [15]. Yeast manoproteins are white or cream or yellow when forming a translucid colloid solution.. Figure 1 is a cross section of the cell wall of yeast.

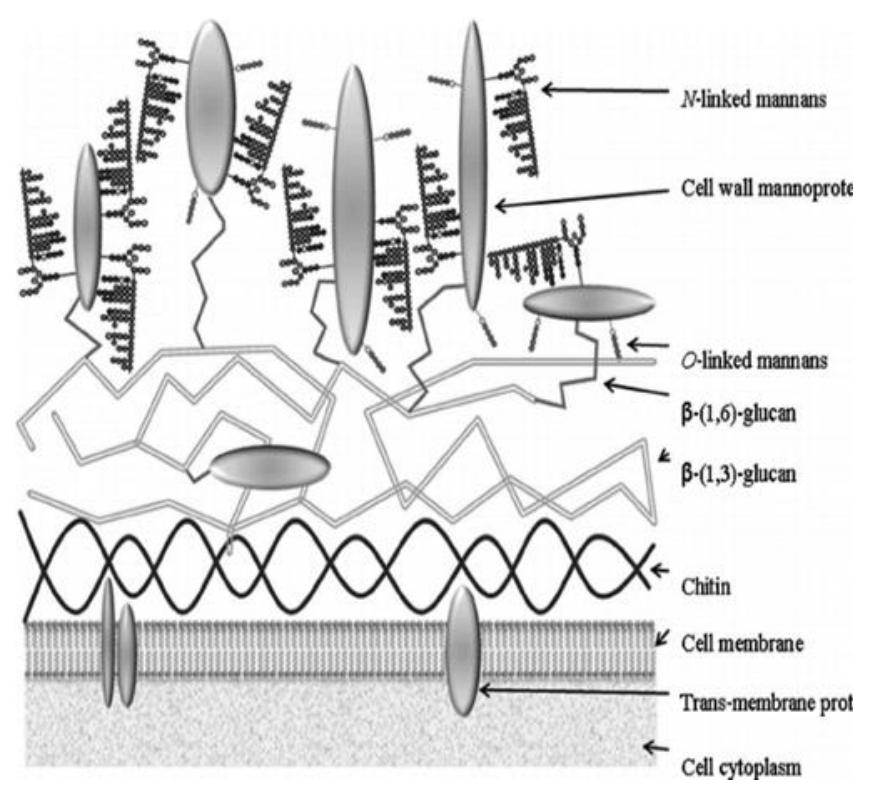

Figure 1. Yeast Cell Wall (Source: Grubb et al., 2008).

The yeast cell wall in general consists of 2 layers by 4 main molecules, namely mannoprotein, $\beta(1,6)$ glucan, $\beta(1,3)$ glucan and chitin. All of these components are connected by covalent bonds. The mannoprotein content in the dry weight of the cell wall is $35-40 \%$, chitin is $1-2 \%, 5-10 \%$ in $\beta-1.6$ glucan and more than half of the cell wall (50-55\%) is composed of $\beta-1,3$ glucans [18]. Figure 2 is the structure of the yeast mannoprotein.

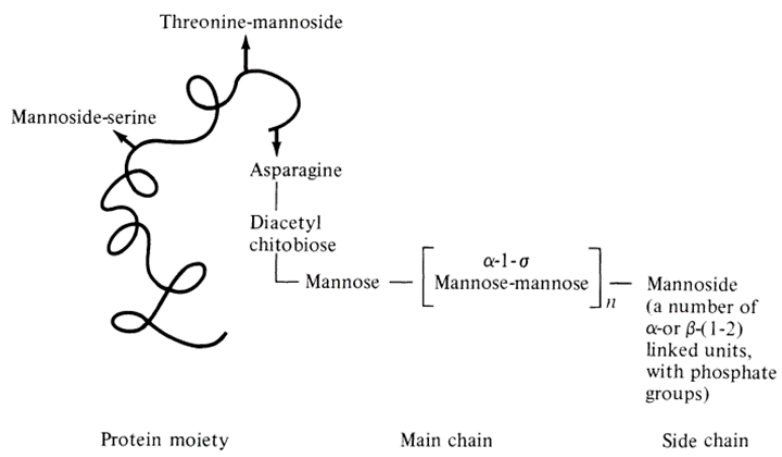

Figure 2. Structure of the Yeast Mannoprotein (Source: Shepherd, 1985)

The structures of the yeast mannoproteins studied so far are molecules with a main chain consisting of Dmannose residues linked by bonds (1-6), to which a varying number of side chains of D-mannose residues are linked to each other by (1-2), a (1-3), a (1-4). The main chain is covalently linked to the protein portion via a tunicamycin sensitive bridge involving asparagine and two N-acetyl-D-glucosamine residues. Short-chain secondary mannosil located on the protein group is attached by O-glycosidic linkages with the hydroxy threonine or serine amino acids, forming alkaline and ether bonds, glycosyl serine, or glycosyl threonine [42].

Mannoproteins have molecular and structural properties, cell wall mannoproteins show a lot of functional-technology so that they have been widely used in the industrial field, one of which is in the food sector. According to Caridi (2006) mannoproteins from yeast cell walls are known to have high emulsification and stabilization power so that mannoproteins are widely used as emulsifiers in salad dressings or mayonnaise without affecting the sensory attributes of these products. Mannoprotein is also widely used in the enology industry because of its ability in the adsorption process of ochratoxin A, complexation with phenolic compounds, increased growth of malolactic bacteria, inhibition of crystallization of tartrate salts, preventing fog formation and strengthening of aromatic components.

\section{Nutritional Modification in Yeasts Growth}

Nutrients are used for growth, cell synthesis, energy needs in metabolism and movement. Nutrients will support each other with an appropriate growth environment for yeast to grow optimally. The enrichment of media with the addition of carbohydrates will provide an opportunity for yeast that does not thrive in the media to grow better. According to Basu et al., (2015) yeast will grow optimally in media with a high carbohydrate source.

Media that can be used in the growth of yeast are food by-products, such as rice bran and cassava peels. Figures 3 and 4 are pictures of rice bran and cassava peel.

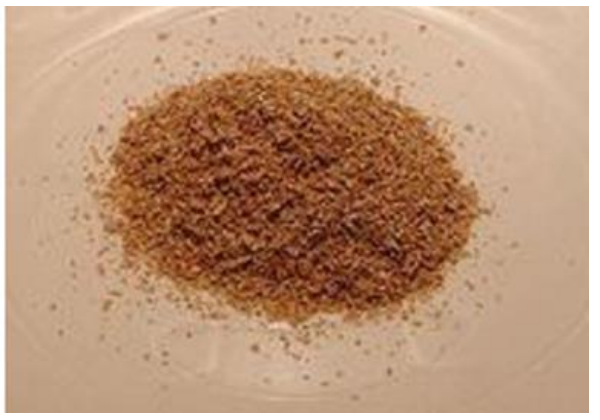

Figure 3. Rice Bran (Source: Auliana, 2011)

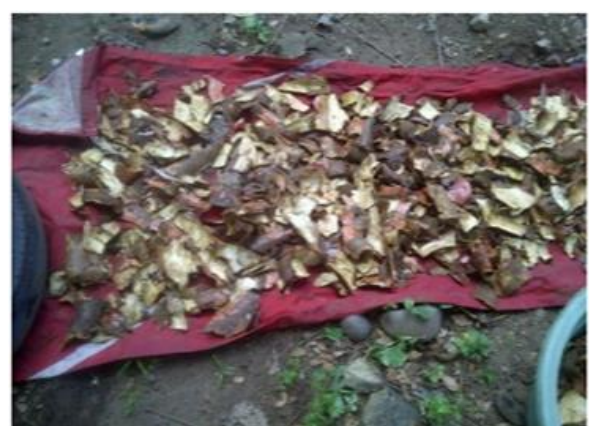

Figure 4. Cassava Peel (Source: Asriani, 2016) 
Rice bran contains about $84.36 \%$ carbohydrates and $8.77 \%$ protein [26]), and contains quite high fat up to $11-23 \%$ [13]. The limitation of using rice bran is due to the ease of rancidity caused by the hydrolysis of fat (triglycerides) to produce glycerol and free fatty acids due to the activity of the lipase enzyme. Free fatty acids are oxidized by the enzyme lipoxygenase to form peroxides, ketones and aldehydes resulting in rice bran rancidity. The treatment was given to suppress the activity of the lipase and lipoxygenase enzymes, namely by stabilizing it. Stabilization itself is the process of maintaining the condition of foodstuffs so that they do not change, both physically, chemically and organoleptically[8].

The process of stabilization or inhibition of lipase enzyme activity that has been widely used is physical means, by heating (by roasting, autoclaving or microwave) [34]. According to Yuniarrahmani, (2001) wet heating of rice bran for 3-5 minutes was able to inactivate the lipase enzyme. The principle of the inactivation of the lipase enzyme is denaturing the protein so that protein conformation occurs which causes the enzyme to become inactive [5] . Damayanti, (2002) states that the stabilization of rice bran using autoclave at $121^{\circ} \mathrm{C}$ for 3 minutes can produce low free fatty acid levels, namely $0.89 \%$ with minimal tocopherol damage with minimal amounts.

Other byproducts of food products such as cassava peels can be used as a yeast growth medium, this is because according to Wachid and Ningrum (2017) cassava peels contain $44-59 \%$ carbohydrates and 1.5 $3.7 \%$ protein. where these nutrients can support the yeast growth. The cassava peel used in this study is the manggu variety of cassava which is generally used by chip producers, this variety comes from Sukabumi, West Java (Alif et al., 2018). In general, anti-nutritional factors are found in cassava skin, namely $\mathrm{HCN}$ ranging from $150-360 \mathrm{mg} / \mathrm{kg}$ [17].

According to Sari and Astili, (2018) there are several processes that can be carried out to reduce $\mathrm{HCN}$ levels, including washing, soaking, cooking and drying. According to Purawisastra (2001) soaking without using $\mathrm{NaHCO}_{3}$ for 6 hours can remove up to $50 \% \mathrm{HCN}$ levels. The results of Fitriani's research (2018) stated that the fermentation activity of cassava peels using Saccharomyces cereviceae for 2 days was able to reduce $\mathrm{HCN}$ levels by up to $99.5 \%$, where at the beginning before fermentation contained $231 \mathrm{mg} / \mathrm{kg}$ of $\mathrm{HCN}$ and after fermentation the HCN levels became $0.47 \mathrm{mg} / \mathrm{kg}$. In addition, fermentation of cassava peels using the bacteria Tricoderma resii was able to drastically reduce $\mathrm{HCN}$ levels from $459.56 \mathrm{ppm}$ to $0.77 \mathrm{ppm}$ [19]. According to Stephanie and Purwadaria, (2013) decreasing the HCN content through fermentation shows a higher effectiveness compared to the washing and drying process, this is because Saccharomyces sereviceae is able to excrete linamarase and $\beta$ glucosidase enzymes so that the degraded cyanide compounds become more free cyanide acid compounds. The difference in the ratio of BKUK composition will affect the availability of nutrients in the media. According to Rezagama and Samudro (2015), media modification with variations in the addition of rice bran will cause an increase in the $\mathrm{C} / \mathrm{N}$ ratio. Purnomo et al., (2017) stated that the $\mathrm{C} / \mathrm{N}$ ratio will affect the activity of yeast to obtain energy sources and cell formation. Yeast will be breaks down compound $\mathrm{C}$ as an energy source and uses $\mathrm{N}$ for protein synthesis. At a $\mathrm{C} / \mathrm{N}$ ratio between 30 to 40 yeast gets enough $\mathrm{C}$ for energy and $\mathrm{N}$ for protein synthesis. If the $\mathrm{C} / \mathrm{N}$ ratio is too high, yeast will lack $\mathrm{N}$ for protein synthesis so that decomposition is slow[47].

In addition to sufficient nutrients, yeast growth and development also require appropriate environmental factors, such as $\mathrm{pH}$ and temperature. . (Cappucino and Sherman (2014) said that yeast growth media requires low acidity ( $\mathrm{pH}$ 4.5-5.6). Some enzymes, electron transport systems and nutrient transport systems in cell membranes are very sensitive (sensitive) to ion concentration. hydrogen $\left(\mathrm{H}^{+}\right)$. This can affect the threedimensional structure of proteins in general, including growth enzymes

\section{The Potential of Yeasts Cell Walls Mannoproteins as Antioxidant}

Free radicals are atoms or molecules that have unpaired electrons in orbitals. Free radicals will attack the nearest stable molecule and take electrons, substances that are taken up electrons will also become free radicals so that it will start a chain reaction, which ultimately results in cell damage [14].

Free radicals are highly reactive and easily lead to uncontrolled reactions, resulting in crosslinking of DNA, proteins, lipids, or oxidative damage to important functional groups on their biomulecules. Lipid peroxidation in cell membranes can create damage to cell membranes by disrupting fluidity and permeability. Lipid peroxidation can also affect the function of membrane bound proteins such as enzymes and receptors. Direct damage to proteins can be caused by free radicals which can affect various types of protein, interfering with enzyme activity and structural protein function.

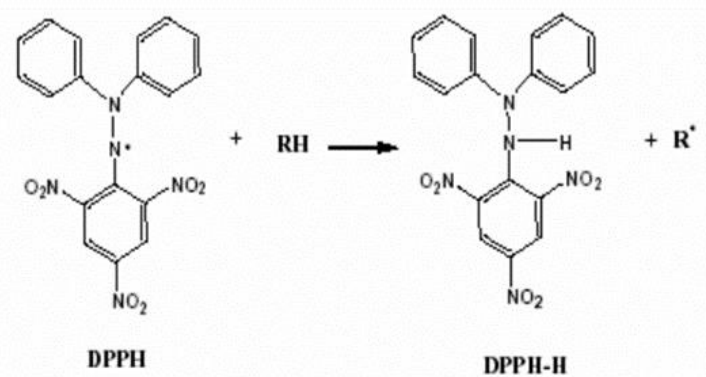

Figure 5. DPPH reduction reaction (Source: Prakash, 2001)

To be able to ward off and suppress the number of radicals, compounds known as antioxidants are needed. Antioxidants are compounds that can inhibit cell damage due to oxidation activity [22]. Antioxidants can stabilize free radicals and complement the deficiency of electrons that have free radicals, and inhibit the chain reaction of free radical formation which can cause oxidative stress [48]. Purwaningsih (2012) states that generally compounds that have antioxidant activity are 
phenolic compounds because they have a hydroxy group. Figure 5 shows a reduction reaction caused by the presence of a compound that can provide a hydrogen atom to the DPPH radical so that it is reduced to DPPH$\mathrm{H}$ (1,2-defenyl-2-picrylhydrazine), causing a change in the color of DPPH.

Antioxidants bring benefits to the health of the human body because they can reduce the effect of oxidation stress [11]. Many components extracted from plants have potential as antioxidants, such as pigments (fukosantin, anthocyanins, carotenoids, etc.) and polyphenols (phenolics, flavonoids, tannins, etc.) [20]. Recently, research has found that mannoproteins derived from yeast cell walls have various biological activities [24].

Mannoprotein has the potential to be an antioxidant because of its constituent compounds, namely mannan and protein, which each produce antioxidant activity. Currently, research has been found which states that carbohydrates can be potential as a new source of antioxidants [33]. Where there is research which states that most of the antioxidant activity of polysaccharides will arise when polysaccharides are combined with several small components [10, 46]. For example, Siu et al., (2014) suggested crude polysaccharides derived from yeast are combined with phenolic and protein components in order to have antioxidant activity.

According to Power et al., (2013) protein is shown to have antioxidant activity. This is because protein is composed of peptides consisting of a series of amino acids, where amino acids act as antioxidants because there are phenol groups in amino acids. Protein and peptide activity depends on the amino acid composition, sequence or structure and hydrophobic. The mechanisms of antioxidant activity can be categorized based on the physicochemical properties of amino acids. For example, residues from aromatic ring structures (Tyrosine, Tryptophan and Phenylalanine) can donate protons to electron-deficient groups [9]. Hydrophobic residues (valine (Val), leucine (Leu) and Tyr) can increase the solubility of peptides in the lipid matrix which increases accessibility to hydrophobic radical species or polyunsaturated fatty acids [31].

\section{References}

1. Alif, Y., Utama, K., and Rukismono, M. 2018. Singkong-Man Vs Gadung-Man (M. T. Ir. Tamaji, M.T., Eddy Lybrecg Takalua, S.T., ed.). Mimika Baru, Papua. Aseni.

2. Asriani. 2016. Organic Ingredients and Crude Protein of Cassava Peel fermented with different inoculants. Thesis, (May), 50. Retrieved From https://Core.Ac.Uk/Download/Pdf/77626470.Pdf

3. Auliana, R. 2011. Benefits of Rice Bran and its Nutritional Content. (April), 1-11..

4. Basu, S., Bose, C., Ojha, N., Das, N., Das, J., Pal, M., and Khurana, S. 2015. Evolution of Bacterial and Fungal Growth Media. Bioinformation, 11(4), 182-184. https://doi.org/10.6026/97320630011182
5. Budijanto, S., Sukarno, S., Kusbiantoro, B., and Sitanggang, A. B. 2010. Inactivation of the Lipase Enzyme for Bran Stabilization as a Functional Food Ingredient. (November), 3-14.

6. Cappuccino, JG., Sherman, N. 2014. Manual of Microbiology Laboratory. Jakarta. Medical Book Publisher Egc.

7. Caridi, A. 2006. Enological Functions of Parietal Yeast Mannoproteins. Antonie Van Leeuwenhoek, International Journal of General and Molecular Microbiology, 89(3-4), 417-422. https://doi.org/10.1007/s10482-005-9050-

8. Caskill, D.R. and Zhang, F. 1999. Use of Rice Bran Oil in Food. Food Technology : 53 (2) : 5053

9. Chen, H. M., Muramoto, K., Yamauchi, F., Fujimoto, K., and Nokihara, K. 1998. Antioxidative Properties of Histidine-Containing Peptides Designed from Peptide Fragments Found in The Digests of a Soybean Protein. Journal Of Agricultural and Food Chemistry, 46(1), 49-53. https://doi.org/10.1021/jf970649w

10. Chen, H., Zhang, M., Qu, Z., and Xie, B. 2008. Antioxidant Activities of Different Fractions of Polysaccharide Conjugates From Green Tea (Camellia Sinensis). Food Chemistry, 106(2), 559-563. https://doi.org/10.1016/j.foodchem.2007.06.040

11. Cook, N. C., and Samman, S. 1996. Flavonoids Chemistry, Metabolism, Cardioprotective Effects and Dietary Sources. Journal of Nutritional Biochemistry, 7(2), 66-76. https://doi.org/10.1016/0955-2863(95)00168-

12. Damayanti, E. 2001. Rice Bran Stabilization and (y) - Oryzanol Content of two Local Paddy Varieties "IR 64" and "Cisadane Muncul". Department of Community Nutrition and Family Resources. Faculty of Agriculture IPB. Journal of Community Nutrition and Family Resources. Faculty of Agriculture IPB. Journal of Technology and Food Industry 7.

13. Damayanti E. 2002. Characteristics of Rice Bran (Oryza sativa) Durable and Antioxidant and Inhibitory Properties of Cancer Cell Proliferation in Vitro of Oil and Fractions. [Dissertation]. Postgraduate IPB, Bogor

14. Droge W. 2002. Free Radicals In The Physiological Control of Cell Function. Physiol Rev. 82;47-95.

15. Farahnejad, Z., Rasaee, M., Yadegari, H., and Moghadam, M. 2004. Purification and Characterization of Cell Wall Mannoproteins of Candida Albicans Using Intact Cell Method. Medical Journal of The Islamic Republic Of Iran (Mjiri), 18(2), 167-172.

16. Fauziah, L., Balia, R. L., and Gumilar, J. 2019. Mannoprotein Production from Candida apicola in the. Scientific Paper Research Management, Economic Enginering in Agriculture and Rural Development, 19(4), 83-88. 
17. Fitriani, 2018. The Effect Of Long The Proses of Fermentation on Levels of Hydrogen Cyanida and Protein Content on The Peel and Cassava Leaves. Teknologi Industri, 12(2), 169-180.

18. Grubb, S. E. W., Murdoch, C., Sudbery, P. E., Saville, S. P., Lopez-Ribot, J. L., and Thornhill, M. H. 2008. Candida Albicans-Endothelial Cell Interactions: A Key Step in the Pathogenesis of Systemic Candidiasis. Infection and Immunity, 76(10), 4370-4377. https://doi.org/10.1128/iai.00332-08

19. Hanifah, V. W., Yulistiani, D. and Asmara, S.A. A. 2010. Optimizing the Utilization of Cassava Bark Waste as Animal Feed in Order to Empower Enye-Enye Business Actors. Proceedings of the National Seminar on Animal and Veterinary Technology. Indonesian Animal Research Institute. Bogor

20. Heo, S. J., Park, E. J., Lee, K. W., and Jeon, Y. J. 2005. Antioxidant Activities of Enzymatic Extracts from Brown Seaweeds. Bioresource Technology, 96(14), 1613-1623. https://doi.org/10.1016/j.biortech.2004.07.013

21. Herscovics, A., Orlean, P., 1993. Glycoprotein Biosynthesis In Yeast. Faseb J. 6, 540-550

22. Kumar, S. 2011. Free Radicals And Antioxidants: Human And Food System. Advances In Applied Science Research, 2(1), 129-135. Kurcz, A., Błażejak, S., Kot, A. M., Bzducha-Wróbel, A., dan Kieliszek, M. (2018). Application of Industrial Wastes for the Production of Microbial SingleCell Protein by Fodder Yeast Candida utilis. Waste and Biomass Valorization, 9(1), 57-64. https://doi.org/10.1007/s12649-016-9782-z

23. Li, J., and Karboune, S. 2018. A Comparative Study for the Isolation and Characterization of mannoproteins from Saccharomyces cerevisiae Yeast Cell Wall. International Journal of Biological Macromolecules, 119, 654-661. https://doi.org/10.1016/j.ijbiomac.2018.07.102

24. Lv, L., Cheng, Y., Zheng, T., Li, X., and Zhai, R. 2014. Purification, Antioxidant Activity and Antiglycation of Polysaccharides from Polygonum Multiflorum Thunb. Carbohydrate Polymers, 99, 765-773. https://doi.org/10.1016/j.carbpol.2013.09.007

25. Maru, V., Hewale, S., Mantri, H., and Ranade, V. 2015. Partial Purification And Characterization of Mannan Oligosaccharides From Cell Wall of Saccharomyces cerevisiae. International Journal of Current Microbiology and Applied Sciences, 4(12), 705-711.

26. Nursalim, Y., and Razali, Z.Y. 2007. Rice Bran is a Healthy Food. Jakarta. Agro Media Pustaka.

27. Power, O., Jakeman, P., and Fitzgerald, R. J. 2013. Antioxidative Peptides: Enzymatic Production, In Vitro And In Vivo Antioxidant Activity And Potential Applications of Milk-Derived Antioxidative Peptides. Amino Acids, 44(3), 797820. https://doi.org/10.1007/s00726-012-1393-9
28. Purawisastra, S. 2001. Detoxification and Increasing Levels of Bitter Cassava Protein. Health Research and Development Agency. http://digilib.litbang.depkes.go.id.

29. Purnomo, E. A., Sutrisno, E., and Sumiyati, S. 2017. Effect of C / N Ratio Variation on Compost Production and Potassium (K), Phosphate (P) Content of Banana Stems with Combination of Cow Manure in Vermycomposting System. Journal of Environmental Engineering, 6 (2).

30. Purwaningsih, S. 2012. Antioxidant Activity and Chemical Composition of the Red Matah Snail. Marine Science, 17 (1), 39-48.

31. Qian, Z. J., Jung, W. K., and Kim, S. K. 2008. Free Radical Scavenging Activity of a Novel Antioxidative Peptide Purified From Hydrolysate Of Bullfrog Skin, Rana Catesbeiana Shaw. Bioresource Technology, 99(6), 1690-1698. https://doi.org/10.1016/j.biortech.2007.04.005

32. Quirós, M., Gonzalez, R., and Morales, P. 2012. A Simple Method for Total Quantification of Mannoprotein Content in Real Wine Samples. Food Chemistry, 134(2), 1205-1210. https://doi.org/10.1016/j.foodchem.2012.02.168

33. Ramarathnam, N., Osawa, T., Ochi, H., and Kawakishi, S. 1995. The Contribution of Plant Food Antioxidants to Human Health. Trends In Food Science and Technology, 6(3), 75-82. https://doi.org/10.1016/s0924-2244(00)88967-0

34. Ramezanzadeh, F. M., Rao, R. M., Windhauser, M., Prinyawiwatkul, W., Tulley, R., and Marshall, W. E. 1999. Prevention of Hydrolytic Rancidity in Rice Bran During Storage. Journal of Agricultural and Food Chemistry, 47(8), 3050-3052. https://doi.org/10.1021/jf981335r

35. Rezagama, A., and Samudro, G. 2015. Takakura Optimization Study with Addition of Husk and Rice Bran. Journal of Precipitation: Communication Media and Environmental Engineering Development, 12 (2), 66. https://doi.org/10.14710/presrecipitation.v12i2.6670

36. Ruiz-Herrera, J., Victoria Elorza, M., Valentín, E., and Sentandreu, R. 2006. Molecular Organization of The Cell Wall of Candida Albicans and its Relation to Pathogenicity. Fems Yeast Research, 6(1), 14-29. https://doi.org/10.1111/j.15671364.2005.00017.X

37. Sari, Fi. D. N., and Astili, R. 2018. Content of Jerky Cyanide from Cassava Peel Waste. World Journal of Nutrition, 1 (1), 20. https://doi.org/10.33085/jdg.v1i1.2899

38. Shepherd, M. 1985. Candida Albicans: Biology, Genetics and Pathogenicity. Annual Review of Microbiology, 39(1), 579-614. https://doi.org/10.1146/annurev.micro.39.1.579

39. Silke C. Jaehrig., Sascha Rohn., Lothar W.. Kroh., and Lutz-G. Fleischer, A. T. K. 2007. In Vitro Potential Antioxidant Activity of Saccharomyces cerevisiae Cell Walls. Yeast, 55(16), 4710-4716. 
40. Siu, K. C., Chen, X., and Wu, J. Y. 2014. Constituents Actually Responsible For the Antioxidant Activities of Crude Polysaccharides Isolated From Mushrooms. Journal of Functional Foods, 11, 548-556.

41. Stephanie, and Purwadaria. 2013. Solid Substrate Fermentation of Cassava Peel as Poultry Feed Material. Wartazoa, 23 (1), 15-22.

42. Tkacz, J. S., and Lampen, J. O. 1975. Tunicamycin Inhibition of Polyisoprenyl N-Acetylglucosaminyl Pyrophosphate Formation in Calf-Liver Microsomes. Biochemical and Biophysical Research Communications, 65(1), 248-257. https://doi.org/10.1016/S0006-291x(75)80086-6

43. Tsiapali, E., Whaley, S., Kalbfleisch, J., Ensley, H. E., Browder, I. W., and Williams, D. L. 2001. Glucans Exhibit Weak Antioxidant Activity but Stimulate Macrophage Free Radical Activity. Free Radical Biology and Medicine, 30(4), 393-402. https://doi.Org/10.1016/S0891-5849(00)00485-8

44. Ugah, U. I., and Nwoba, S. T. 2018. Microbial Media Formulation Using Rice Husks, Yam and Cassava Peels on Some Selected Microorganisms. Scientific Research, 26(1), 122-131. https://doi.org/10.5829/idosi.mejsr.2018.122.131

45. Wachid, M., and Ningrum, D. A. 2017. Media from Cassava Peel for the Growth of Saccharomyces cerevisiae and Application to Bread. National Seminar and Product Title, (1), 592-599.

46. Wang, Z., and Luo, D. 2007. Antioxidant Activities of Different Fractions of Polysaccharide Purified from Gynostemma pentaphyllum Makino. Carbohydrate Polymers, 68(1), 54-58. https://doi.org/10.1016/j.carbpol.2006.07.022

47. Wulan, PPDK, Gozan, M., and Arby, B., Kimia, DT, Teknik, F., Indonesia, U., Fax, T. 2005. Determination of the Optimal C: N: P Ratio as Nutrients in the Biodegradation Process of Benzene-Toluene and Bioregenerator Column Scale Up.

48. Yaessh, S., Jamal, Q., Khan, A. U., and Gilani, A. H. 2006. Studies on Hepatoprotective, Antispasmodic and Calcium Antagonist Activities of The Aqueous-Methanol Extract of Achillea Millefolium. Phytotherapy Research, 20(7), 546551. https://doi.org/10.1002/ptr.1897

49. Yuniarrahmani C. 2001. Preserving Bran with Physical Treatment: Heating Using a Drum Drier, Extruder, Roasting, Steaming and Autoclave. [thesis] Bogor: Faculty of Agricultural Technology, Bogor Agricultural University 